Australian continent-as exemplified by the theory of a peneplane extending from New Guinea to Tasmania -Dr. Daneš cannot bring himself to accept, at all events in their entirety, the views of previous observers with regard to the establishment of present conditions. To put the matter briefly, he considers that the peneplane of eastern Australia was divided into a number of basins devoid of outlet and occupied by shallow lakes, which tended to dry up during prolonged drought, such lakes being, therefore, of independent origin, and not "cut-offs." Climatic conditions were then much more favourable to the development of an abundant flora and fauna, which will explain the occurrence of the great extinct marsupials in the Pleistocene beds of Darling Downs. Desiccation of the area led to the death of the old fauna and flora.

In this respect he is in accord with Dr. A. C. Gregory, who wrote that "there is no trace either in the Darling Downs or any other part of Queensland of any violent convulsion of nature which would be adequate to cause the total destruction of the diprotodon and co-occupants of the country, and it seems most probable that their extinction resulted from a gradual change of climate and more effectual drainage of the ivatercourses-aided, perhaps, by some slight changes in level."

R. I..

\section{SOME ENGLISH PUBLICATIONS ON AGRICULTURAL SCIENCE.}

$\bigcirc^{\mathrm{F}}$ the numerous agricultural periodicals and journals published in Great Britain none is more important than the Journal of the Royal Agricultural Society, which comes out annually, and gives some account of advances that have been made in the practice or the science of agriculture during recent times. The current issue is the seventy-second volume, publication having been continuous ever since 1840; although smaller in bulk than some of the old volumes, it well maintains the high standard set by Mr. Mackenzie when he took over the editorship some four years ago.

The opening article, by Prof. T. B. Wood, gives an able summary of our present knowledge of the composition and food value of bread. Probably no single product possesses greater interest to the agriculturist than wheat, even though in many cases it has fallen to the level of a by-product, and has ceased to be the staple of the farm. The advances in milling technique have led to considerable alterations in the relative values of the different wheats; formerly a white wheat possessed chief value because it gave the whitest flour, while now a red wheat is equally useful. Recently the hard wheats of great strength have come into favour, because of their capacity for making a large loaf; these wheats are more economically produced in continental areas-Canada, the United States, \&c.-than here. In general, however, flour is made from a mixture of wheats carefully graded to secure certain definite characters. This blended flour does not show the deficiencies in protein, \&c.. that an unblended flour would show in comparison with the whole grain, so that a usual argument in favour of brown bread loses much of its force. This paper is followed by one on the milling of wheat, by Mr. A. E. Humphries. Of the other papers, one on green crops, by Prof. Malden, is of more than technical interest, and shows that the ordinary agriculturist does not utilise as fully as he might certain plants that would be very useful to him.

An interesting investigation on ropy milk has been published by Mr. J. Golding in the Journal of the Board of Agriculture (No. I2). This is a disease of milk brought about by bacteria, and causing the milk to take on a rope-like form when poured from a jug, or to draw out into long threads, sometimes a yard in length, when taken up in a spoon. Several bacteria are known that can effect this change, and one of them, the Bacillus lactis viscosus of Adametz, was investigated in some detail.

The possibility of growing tobacco in England is being investigated at the Wye Agricultural College by Mr. G. H. Garrad. It is proposed to grow the crop for the sake of its nicotine, which forms an admirable insecticide, but is at present very costly for the grower. Messrs. Garrad and Edwardes-Ker conclude that extraction of the nicotine from the leaf is not necessary, satisfactory washes being obtained when the leaves are simply macerated in water. Permission to grow tobacco for this purpose could not be obtained unless the leaves could be denatured so thoroughly as to be unsmokable. The authors are at present at work endeavouring to find some method of doing this.

\section{GRANTS FOR SCIENTIFIC PURPOSES FROM THE DEVELOPMENT FUND.}

A MEMORANDUM showing advances from the A Development Fund, sanctioned by the Lords Commissioners of his Majesty's Treasury, to or through the Board of Agriculture and Fisheries, up to March 31, 1912, has recently been published as a Parliamentary Paper [Cd. 6252] (price $\mathrm{I}_{\frac{1}{2}} d$.). The subjoined extracts show the amounts and purposes of the grants.

\section{(I) Improvement of Light Horse Breeding.}

In Ig io the Board applied for an advance from the Development Fund in respect of a scheme for the improvement of light horse breeding, and in January of the following year the Treasury, on the recommendation of the Development Commissioners, sanctioned an advance of $39,800 l$. to be expended generally on the lines of the scheme proposed by the Board.

A further grant of a sum not exceeding $1250 l$. was also sanctioned to meet the expenses of administration. In August, I9II, the Treasury, on the recommendation of the Development Commissioners, sanctioned an advance of an additional sum not exceeding ro,oool. for allocation before March 31, I9I2, to enable county committees to purchase brood mares in time for the breeding season of 1912 , the original grant of Io,oool. having been allocated early in the financial year $191 \mathrm{I}-12$ for the purposes of the breeding season of rgrr.

The Treasury, on the recommendation of the Development Commissioners, has sanctioned an advance of $40,000 l$. or such part thereof as may be required in respect of the scheme, in the financial year $1912-13$.

\section{(2) Agricultural Research.}

\section{(i.) Interim Advances.}

The Board made an application for an advance of jo,oool. per annum from the Development Fund for the organisation of a system to aid and develop agriculture by promoting scientific research and experiment, and for the provision of technical aid and advice to agriculturists. The Treasury, on the recommendation of the Development Commissioners, has sanctioned an interim advance of such part of a sum of $9706 l$. as might be required in the financial year I9II-I2 for the purpose of making the following grants :-

No. 223 I, VOL. 89] 
Cambridge University 40ool. for research work. Bristol University ... 50ol. for (I) biochemical investigations on cheese ; (2) investigations on Teart land.

Yorkshire Council for Agricultural Education (Leeds University)

University Reading

College,

South-Eastern Agricultural College, Wye

$2 \mathrm{Iol}$. for investigations of atmospheric impurities.

25ol. for general work on

(I) microflora of cheese ;

(2) cereal selection.

$350 l$. for (1) investigations on tobacco; (2) mycological department ; (3) entomological department; (4) investigations on hop resins

University College of $156 l$. for botanical survey Wales, Aberystwyth of Aberystwyth: and subsidiary inquiries.

Harper Adams Agricul- 19ol. for research on wart tural College

Roval Veterinary Col- r39ol. for investigations in lege

The Incorporated So- 200ol. for research work. ciety for extending the Rothamsted Experiments

The British Dairy Institute, Reading ...

$60 l$. for investigation into the manufacture of cheese from heated mills.

Woburn Experimental 6ool. for experimental Station work.

The Treasury, on the recommendation of the Development Commissioners, has sanctioned a further interim advance to the Board of a sum not exceeding $950 l$., or such part thereof as might be required in the financial year $1911-12$, for the purpose of making the following grants : -

(I) $200 l$. to the Economic Ornithological Committee of the British Association, to enable it to continue and extend its work of investigating the feeding habits of British birds. It was made a condition of this grant that the Board should, out of its own vote, make a grant to the committee of a sum of $50 l$. in the year I9II I2.

(2) 5ool. to the Imperial College of Science and Technology towards the current expenses of the Department of Plant Physiology.

(3) Such sum as may be necessary, but not in any case to exceed 5ol., to the Yorkshire Council for Agricultural Education, to defray expenses connected with $\mathrm{Mr}$. T. H. Taylor's investigations into the swede midge.

(4) $200 l$. to the Midland Agricultural and Dairy College for research into the discoloration of Stilton cheese.

(ii.) General Scheme.

The Treasury has informed the Board that it had received the final recommendations of the Development Commissioners on the Board's application for the advance of $50,000 l$. per annum referred to above, and that it had sanctioned the following scheme :-

(I) Grants to Colleges in Aid of the Extension of Advisory and Local Investigation Work.-An annual advance to the Board of a sum not exceeding $12,000 l$. for apportionment between twelve colleges so situated as to cover the whole country.

NO. 223 I, VOL. 89]
(2) Research Scholarships.--An advance to the Board of a sum of $16,500 l$. for the provision of 36 scholarships of the value of $150 l$. each per annum, tenable for the period of three years; 12 to be given in I9II, I2 in I9I2, and 12 in I9I3. The advance will include fees of selection, and will, it is expected, be spread over the five years 19 II-12 to $1915^{-16}$ inclusive.

(3) Grants to Institutions in Aid of Scientific Research and Experiment.-An annual advance to the Board of a sum not exceeding $30,000 l$. to provide for the carrying out of work on the following eleven subjects at the institutions specified in each case:-

(a) Plant physiology ... Imperial College of Science and Technology.

(b) Plant pathology, my- A special department of the cological side Royal Botanic Gardens, Kew.

(c) Plant Breeding ... Cambridge University and the John Innes Institution.

(d) Fruit Growing $\quad \ldots$ The main centre will be at the National Fruit and Cider Institute at Long Ashton (in connection with the Bristol University), and there should be two or three subsidiary stations situated in the chief fruit-growing districts.

(e) Plant nutrition and Rothamsted Experimental soil problems

(f) Animal nutrition ... Cambridge University and another Institute to be settled later.

(g) Animal breeding ... Two institutes to be settled later.

In the meantime the Commissioners agreed to a grant of $400 l$. for work on the breeding of small animals.

(h) Animal pathology ... The Royal Veterinary College and the Board's Veterinary Laboratory.

(i) Dairy investigation ... The University College, Reading, or another suitable institution.

(j) Agricultural zoology... To be divided possibly between two universities, one being given economic entomology and the other general zoology, especially helmintology.

(k) Economics of agri- Oxford University. culture

The Commissioners stated that they would be prepared to consider applications for a grant of $5^{\circ}$ per cent. of the capital expenditure required for the establishment of some of the institutions, leaving the other 50 per cent. to be raised by the institution or locality concerned, unless there were very special circumstances to justify a larger grant from the Development Fund.

(4) Special Investigations and Researches.-An annual advance to the Board of a sum not exceeding $3000 l$. to be allocated for the assistance of particular investigations and researches not otherwise provided for.

Provision for I9I I-12.-The Treasury, on the recommendation of the Development Commissioners, sanctioned an advance to the Board of a sum not exceeding $3000 l$. to meet the expenses involved in 
such parts of the scheme as could be started before March 3I, I9I2,

Provision for I912-13.-The following sums have been provided in the Board's Estimates for I912-13 :-

Part expenses of administration, in- $£ £$ cluded in subhead A, salaries, wages, and allowances ...

Other expenses of the scheme, included in subhead $\mathrm{G}:-$

Grants to colleges in aid of the extension of advisory and local investigation work ... ...

Research scholarships (including expenses of selection) ... ...

Grants to institutions in aid of scientific research and experiment investigations an $\ldots$ searches ( $900 l$. not repayable from the Development Fund)

Inquiries, experiments, \&c., by or on behalf of the Board (not repayable from the Development Fund) $\quad \ldots \quad \ldots \quad \ldots \quad \ldots$

Assistance on questions of economic zoology (not repayable from the Development Fund) ...

\section{9,000}

2,800

20,000

3,900

400

200

Total provision in $1912-13$ for agricultural research

Deduct -

Annual provision already made under the Board's vote in respect of agricultural research and not repayable from the Development Fund (see above)

Amount repayable from the Development Fund and included in subhead $\mathrm{S}$-appropriations in aid

(3) FArm Institutes.

The Treasury, on the recommendation of the Development Commissioners, has sanctioned an advance to the Board of a sum of $80,000 l$., or such part thereof as might be required in the period ending on March 3I, I9I3, subject to the following conditions among others :-

(a) That only such farm institutes are established and maintained as the Board may consider necessary, having regard to the possibility and advantages of combining counties for the purpose;

(b) That not more than 75 per cent. of the capital cost of provision of an institute be defrayed from the Development Fund;

(c) That the Development Fund bear only such part of the annual cost of maintenance of a farm institute or school (including the instruction and educational facilities provided by county councils at, or in connection with, it) as may be required to make up to 50 per cent. the proportion borne by central funds, after taking account of any Parliamentary grants which may be forthcoming.

The Development Commissioners also expressed their willingness to recommend further annual advances from the Development Fund in aid of the scheme up to a total limit of $325,000 l$. for the period ending on March 3I, I9I6.

The sum provided in respect of the scheme in the Board's Estimates for Ig12-13 (subheads L and S) is 1o,oool. only, as arrangements for carrying out the scheme were not sufficiently advanced to admit of a definitive estimate being made of the sum required for the purpose in $1912-13$.

NO. 223 I, VOL. 89]
(4) Development of Forestry.

The Board made an application to the Treasury for grants amounting to 95,oool. for the development of forestry in England and Wales, to be expended during the period from October I, I9II, to March 3I, I9I4. Correspondence with respect to this application is proceeding between the Board and the Development Commissioners, but in the meantime the under-mentioned grants have been sanctioned by the Treasury.

(a) Advisory Work.-An advance of a sum not exceeding $2500 l$. per annum for a period of three years, to meet salaries and travelling allowances, at five centres to be selected for advisory work. Two of these centres (Oxford and Cambridge) to be equipped for higher education in forestry, and the remaining three centres (Bangor, Newcastle, and Cirencester) for forestry education of a lower grade.

(b) Research.-An advance of a sum of roool. per annum for two years, to enable Oxford and Cambridge to provide in each case for the salary and expenses of a research officer: and an advance of $200 l$. per annum for two years for research work outside these two universities, provided that such research is carried out at Bangor, Cirencester, or Newcastle.

The advances under this head to be conditional on the work being confined to investigations into the diseases of indigenous trees and the structure of indigenous timber, and of such exotics as have been proved or may be shown to be of commercial importance to the United Kingdom.

(c) Minor Forestry Experiments.-An advance of roool. per annum for the preparation and upkeep of sample plots on condition that the Board arrange for the selection of the plots for the local management of the experiments through the staff of the forestrv centres where these plots are situated.

(d) Administration.-An advance to the Board of such a sum as the Treasury may sanction, but not to exceed $28 \mathrm{Iol}$., for the period from October I, I9II, to the end of the financial year 19I3-14.

Provision for 1912-13. - The following sums have been provided in the Board's Estimates for $1912-13$ :-

Grants for education (not repayable from the

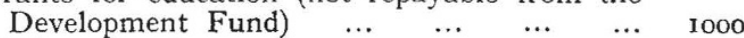
$\begin{array}{lllllll}\text { Advisory work } & \ldots & \ldots & \ldots & \ldots & \ldots & 2500\end{array}$ $\begin{array}{llllllll}\text { Research } & \ldots & \ldots & \ldots & \ldots & \ldots & \ldots & 1200\end{array}$

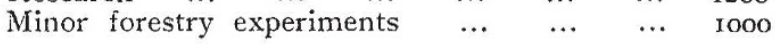

Total provision (subhead $\mathrm{H}$ ) in $1912-13$ for development of forestry ... ...

5700

Deduct-

Annual provision already made under the Board's Vote in respect of forestry and not repayable from the Development Fund (see above) ....

1000

Amount repayable from the Development Fund and included in subhead $\mathrm{S}$-appropriations in aid ... $f 4 ; 00$

\section{(5) Agricultural Cooperation.}

The Treasury, on the recommendation of the Development Commissioners, sanctioned an interim advance of $3000 l$., or such part thereof as might be required in IOII-I2 as a grant to the Board to be held by it in trust for the Agricultural Organisation Society.

(6) Fishery Development.

The Treasury, on the recommendation of the Development Commissioners, has sanctioned the following interim advances to the Board, or such portions thereof as might be required before March 3I, 
I9I3, in respect of a scheme for the development of the fisheries of England and Wales :-

(I) A sum not exceeding $600 l$. for work in connection with lobster fisheries;

(2) A sum not exceeding $3500 l$. in aid of the Board's general research work;

(3) A sum not exceeding 159ol. for the purpose of making the following grants or such portions thereof as might be required before March 3I, I9I3, to the institutions named, viz. :-

(a) 1240l. to the Lancashire and Western Local Fisheries Committee.

(b) $300 l$. to the Marine Biological Association in aid of their research work.

(c) 5ol. to the Eastern Local Fisheries Committee in aid of their experiments in connection with the marking of crabs and lobsters.

\section{British Beekeepers' Association.}

The Treasury, on the recommendation of the Development Commissioners, has sanctioned a grant to the British Beekeepers' Association of a sum not exceeding $850 l$. as follows :-

(I) A sum of $350 l$. for an experimental apiary in some central situation, to be fitted with all modern appliances and to be used for demonstration purposes and in connection with the training and examination of lecturers.

(2) A sum equal to the income of the association for the current year, but in no case to exceed $500 l$., for general organisation-including the training and examination of lecturers, the promotion of county associations, and the organisation of pioneer lectures and demonstrations.

\section{THE STATE UNIVERSITIES OF FRANCE.}

$A$ MONG the signs of progress to be noted is the increase in the number of students. As shown by the table, this increase has been marked during the decade I9oI-Io, excepting in the case of one or two of the universities. At these smaller centres a process of scholastic specialisation has been going on which promises to give them distinctive place in the general system.

Distribution of Students in the State Universities of France.

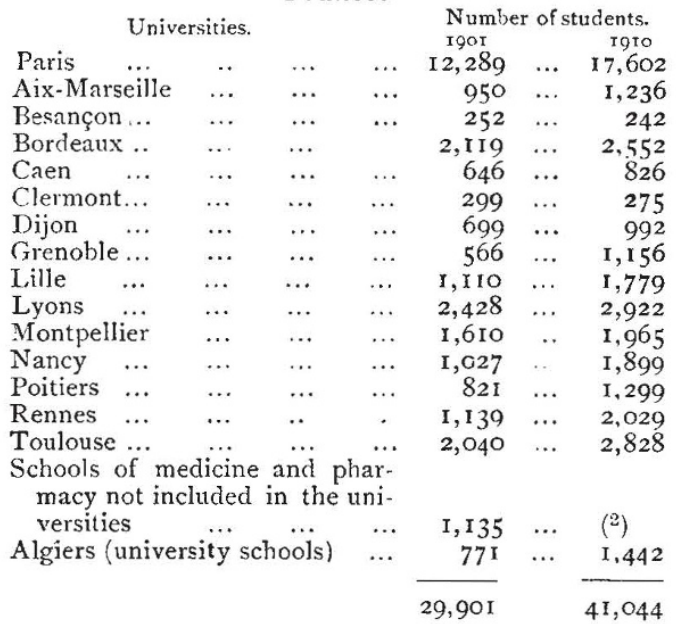

In the decade covered by the table the total number of students rose from $29,90 \mathrm{I}$ to $4 \mathrm{I}, 044$, an increase of

1 Abridged from a chapter on Educational Movements in Western Europe, by Anna $T$. Smith, in the report of the U.S. Commissioner of Ellucation for the year ended June 30 , I $91 \mathrm{I}$.

2 Included in the universities in rgro.
37 per cent. For the University of Paris alone the increase was above the average, amounting to 43 per cent.; for the provincial universities, taken together, the increase was 33 per cent. The contingent of foreign students has contributed in a marked degree to this advance; in 1900 they numbered 1770 ; in 1910 $524 \mathrm{I}$, a gain of $196^{\circ} 6$ per cent. during the decade. These numbers pertain to the winter sessions; in the summer sessions the number of foreigners is always greater; for instance, in 1910 , it was 5800 , or 559 more than in the winter session of the same year. The numbers quoted relate solely to regularly inscribed students. No account is taken of students attending public lectures at the Collège de France, the Muséum, or the Conservatoire des Arts et Métiers. This proof of the extending reputation of the universities affords just gratification to the French authorities, who dwell also upon the evidence that it affects nearly every country. Russia has the largest representation in the student body, and the German Empire, exclusive of Alsace-Lorraine, stands second in this respect.

The universities of France, like those of Germany, are highly specialised institutions in which students are prepared for professional or official careers. General education is the province of the lycées and colleges which prepare students for the bachelor's degree, a prerequisite for matriculation at the universities. Hence the distribution of students by faculties serves as an index to the changing currents of intellectual life and of university demands in France.

Distribution of Students among the Different Faculties of the State Universities of France.

\begin{tabular}{|c|c|c|c|c|c|}
\hline \multirow{2}{*}{ Faculties. } & & & \multicolumn{3}{|c|}{$\begin{array}{l}\text { Number of students in } \\
\text { State universities. }\end{array}$} \\
\hline & & & $\begin{array}{l}\text { Jan. Is, } \\
\text { rgor }\end{array}$ & & $\begin{array}{l}\text { Jan. } 15, \\
1910\end{array}$ \\
\hline$\cdots \quad \ldots$ & $\ldots$ & $\ldots$ & 10,152 & $\ldots$ & 16,915 \\
\hline$\cdots$ & $\ldots$ & $\ldots$ & 8,627 & $\ldots$ & $9,72 \mathrm{I}$ \\
\hline$\ldots$ & $\cdots$ & $\cdots$ & 3,910 & $\ldots$ & 6,287 \\
\hline$\cdots$ & $\ldots$ & $\ldots$ & 3,723 & $\ldots$ & 6,363 \\
\hline & $\ldots$ & $\ldots$ & 3,347 & $\ldots$ & $1,75^{8}$ \\
\hline & $\cdots$ & $\cdots$ & 142 & $\cdots$ & - \\
\hline & & & & & , \\
\hline
\end{tabular}

From the distribution of the students among the different faculties, as shown in the table, it is seen that law attracts nearly 40 per cent. of the entire number, and, further, that the faculty of letters has gained upon the faculty of sciences, which at the beginning of the decade had the larger registration. This increasing attendance upon the faculty of letters is due in great measure to the changing requirements of the teaching force of the secondary schools, which is recruited chiefly from the two faculties considered. Among other causes for the gain in letters is the preference of foreign students. The number of foreigners in the faculties of science rose in the decade from 278 to 1208 , an increase of 334 per cent.; in letters from $21_{5}$ to 1708 , an increase of 694 per cent.

The increased attendance upon the faculties of letters and science is due in part to the system of bourses (scholarship funds) adopted by the Government in the early days of the Republic, with the purpose of assuring a sufficient number of candidates for the teaching service of secondary schools. At that time the faculties were purely examining juries and few candidates were forthcoming for the licence (diploma required for regular scholarships) or for the agrégation (examination for special professors). In order to induce young men of promise, but of limited means, to enter the service, Government bourses were created to be awarded upon competitive examination. The number of candidates admitted to this provision each year is, however, strictly limited, and at present the boursiers form a very small propor- 